\title{
DVFB 制御を保持するロバストモデルマッチングの
}

\section{拡張*}

花島 直彦**. 正田 弘光**. 山下 光久**

\section{An Extension of The Robust Model Matching Keeping DVFB Control*}

Naohiko HanajImA**, Hiromitsu Hikita** and Mitsuhisa Yamashita**

\section{1.はじめに}

柔軟宇宙構造物などの姿勢制御では, 弾性振動に起因 する不安定現象を抑制しながら, 精度良く目標方向へ指向 制御することが要求される。このような制御に対し, ロバ スト制御の立場から様々な研究があり, 筆者らも DVFB (Direct Velocity FeedBack) 制御とロバストモデルマッ チング (以下, RMM) を併用する手法を示している1).

この手法は制御対象がフルランクであることを仮定し ている、ところが，制御系設計用モデルの剛体モードと 振動モードの数よりもアクチュエータの数が多い場合に はこの仮定が成り立たない. ますます大規模化する宇宙 構造物の制御のためにこの制限の緩和が望まれる。本速 報では，この仮定が成り立たなくなるときの条件を示し， 制限を緩和するための新たな手法を提案する.

以下では, $n$ 次の実数べクトルを $\boldsymbol{R}^{n}, n$ 行 $m$ 列の実 数行列を $\boldsymbol{R}^{n \times m}, n$ 行 $m$ 列の多項式行列を $\boldsymbol{F}^{n \times m}, n$ 行 $m$ 列の有理関数行列を $\boldsymbol{M}^{n \times m}$, システム $G$ の入力 ベクトル $a$ から出力ベクトル $b$ までの伝達関数行列を $G_{a b}, n$ 次の単位行列を $I_{n}$, 行列 $A$ の転置を $A^{\mathrm{T}}$ と記 述する.

\section{DVFB 制御を保持する RMM}

\section{1 制御対象}

本手法では制御対象を以下のようにおく2).

$$
\begin{aligned}
& A \ddot{q}+B \dot{q}+C q=\Psi^{\mathrm{T}} u+e \\
& y_{p}=\Psi q \\
& y_{r}=\Psi \dot{q}
\end{aligned}
$$

ここで, $q \in \boldsymbol{R}^{n_{q}}$ は剛体モード, 柔軟モードからなるべク トル,$u \in \boldsymbol{R}^{m}$ はアクチュエータのトルク, $y_{p}, y_{r} \in \boldsymbol{R}^{m}$

* 原稿受付 1996 年 9 月 4 日

** 室蘭工業大学 Muroran Institute of Technology; 27-1, Mizumoto-cho, Muroran city, Hokkaido 050, JAPAN Key Words: robust model matching, DVFB control, collocated feedback, flexible structures.
はそれぞれセンサから得られる変位, 速度, $e \in \boldsymbol{R}^{n_{q}}$ は概 念上の入力, $A$ は慣性を表す正定行列, $B, C$ はそれぞ れ粘性, 剛性行列を表す準正定行列, $\Psi$ はアクチュエー 夕の配置で決まるモード座標でフルランクとする。(2), (3) 式 はセンサとアクチュエータが同じ場所に配置され ていることを表しており,これを collocation と呼んで いる.

\section{2 従来法}

RMM は既存の制御系に対し，ロバスト性向上のため の付加制御器（ロバスト補償器）を追加する設計法であ る. ロバスト補償器の構成の考え方は; 制御対象の不確 かさや特性変動が制御量と可測量に及ぼす影響を等価外 乱という仮想的な外乱に起因守るものととらえ，等価外 乱の推定，打ち消しを行うというものである.

Fig. 1 に制御系の構成図を示す. $r \in \boldsymbol{R}^{m}$ は目標值入力, $h \in \boldsymbol{R}^{m}$ は既存制御器の適当な入力, $v \in \boldsymbol{R}^{m}, \bar{v} \in \boldsymbol{R}^{m}$, $v^{\prime} \in \boldsymbol{R}^{m}$ はそれぞれ信号 $y_{p}, y_{r}, z \in \boldsymbol{R}^{m}$ に加わる概念 上の入力, $\bar{d} \in \boldsymbol{R}^{2 m}$ はすべての等価外乱を表しうる基本 的な等価外乱, $\hat{d} \in \boldsymbol{R}^{l}$ は実際に打ち消すべき等価外乱で ある.ささらにここで, $y^{\star}=\left[y_{p}^{\mathrm{T}} y_{r}^{\mathrm{T}}\right]^{\mathrm{T}}, w^{\star}=\left[w^{\mathrm{T}} \bar{w}^{\mathrm{T}}\right]^{\mathrm{T}}$,

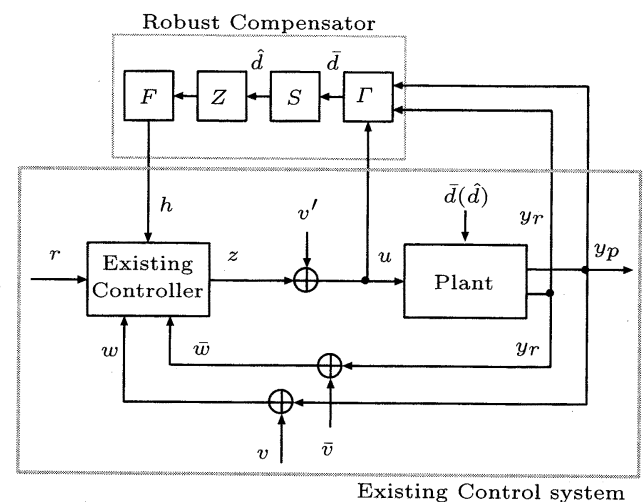

Fig. 1 Block diagram of the RMM system 
$v^{\star}=\left[v^{\mathrm{T}} \bar{v}^{\mathrm{T}}\right]^{\mathrm{T}}$ を定義しておく. 各システムの伝達関数表 現は制御対象を $P$, 既存制御器を $C$, 既存制御系を $W$, $\mathrm{RMM}$ の付加制御器であるロバスト補償器を $R, C$ と $R$ からなる制御器を ${ }_{R} C, W$ と $R$ からなる制御系全体を ${ }_{R} W$ とする.

ロバスト補償器は, $u, y_{p}, y_{r}$ から $\bar{d}$ を推定する $\Gamma \in$ $\boldsymbol{F}^{2 m \times 3 m}, \bar{d}$ から $\hat{d}$ を生成する $S \in \boldsymbol{F}^{l \times 2 m}, \hat{d}$ からのゼ ロイングを行う $Z \in M^{m \times l}$, 制御器全体がプロパ性を満 足するように付加するローパスフィル夕 $F \in M^{m \times m}$ で 構成する. $\Gamma$ は $P_{u y^{\star}}$ の多項式左分解から求められる. $S$ は設計者が設定できる設計パラメータである， $Z$ は次 のゼロイングの条件式

$$
{ }_{R} W_{\hat{d} y_{p}}=W_{\hat{d} y_{p}}+W_{h y_{p}} Z=0
$$

を満たすように次のように決められる。

$$
Z=-W_{h y_{p}}^{-1} W_{\hat{d} y_{p}}
$$

$F$ がダイナミクスを持つので, ロバスト補償器により厳 密なゼロイングはできないが, $F(j \omega) \approx I_{m}$ である周波数 帯では近似的にゼロイングが達成される。「がオブザー バの役割を果たすためロバスト補償器のモードは不可制 御となる. 制御対象 $P_{u y}$ が最小位相系の場合, $Z$ は安 定, 普通 $S, F$ も安定であるように選ぶので，ロバスト 補償器付加後の制御系全体では既存制御系の安定性が維 持される。

既存制御系は $y_{p}, y_{r}$ に対してそれぞれ負定のフィード バック行列で構成する。これは collocated feedback 制御 と呼ばれ, 制御対象の正実性を利用し制御系の安定性を保 証する. 特に速度 $y_{r}$ のフィードバック行列 $C_{\bar{w} z}$ は DVFB 制御と呼ばれ, 柔軟構造物の減衰係数を全周波数帯にわ たって増加する.ロバスト補償器の出力は $C_{w^{\star}} z$ の多項 式左分解の分解点 $h$ に入力する. collocated feedback 制御の場合 $C_{h z}$ は逆行列を持つ定係数行列となる.

この制御系において, ロバスト補償器の要素 $S, F$ が 次の条件を満足するとき, ロバスト補償器の付加前後で $C_{\bar{w} z}$ のループ, すなわち DVFB 制御が不変となる.

$$
\begin{aligned}
S & =I_{2 m} \\
F & =f I_{m}
\end{aligned}
$$

ここで, 伝達関数 $f \in M$ は適当な相対次数のローパスフィ ルタである、ローパスフィルタ $f$ のバンド幅は, $\mathrm{RMM}$ 適用後の制御系の低感度帯域を調整するパラメータとな る. $f$ のバンド幅内では低感度化のため制御系全体がハ イゲインとなり, RMM 適用前に比べ振動が生じやすく なる.このため, $f$ を調節する際に DVFB 制御の減衰 効果を維持しておくことは, 見通しのよい設計のために
有効である。

\section{3 従来法の制限}

2.2 で示した従来法では (5) 式で $W_{h y_{p}}=P_{u y_{p}}(I-$ $\left.C_{w^{\star} z} P_{u y^{\star}}\right)^{-1} C_{h z}$ が逆行列を持つことを仮定している. $W_{h y_{p}}$ の $P_{u y_{p}}$ 以外の因子は逆行列を持つので, この仮 定は $P_{u y_{p}}$ がフルランクであることに等価である.

(1) (3) 式をラプラス変換してまとめると次のように なる.

$$
\begin{aligned}
q & =L \Psi^{\mathrm{T}} u+L e \\
y_{p} & =\Psi L \Psi^{\mathrm{T}} u+\Psi L e \\
y_{r} & =\Psi s L \Psi^{\mathrm{T}} u+\Psi s L e
\end{aligned}
$$

ここで $L \in \boldsymbol{M}^{n_{q} \times n_{q}}$ は次式の伝達関数行列である.

$$
L \equiv\left(A s^{2}+B s+C\right)^{-1}=P_{e q}
$$

(9) 式で, $u$ から $y_{p}$ までの伝達関数行列 $\Psi L \Psi^{\mathrm{T}}$ が $P_{u y_{p}}$ にあたる。この式からわかるように, $\Psi$ が縦長の場 合には $P_{u y_{p}}$ はフルランクにならない.したがって,この とき従来法は適用不可能になる。具体的には, アクチュ エータの数が制御系設計モデルのモードの数より多い場 合がこれに該当する。

\section{3. 従来法の拡張}

(5) 式において $W_{h y_{p}}$ にあたる行列がフルランクでは なくても右疑似逆行列を持てばゼロイングは達成可能で ある。このことに着目して従来法を拡張する。ここでは， $y_{p}$ の代わりに制御対象の各モードの変位 $q$ をゼロイン グに用いる方法を提案する。このとき新たなゼロイング の条件式は次のようになる。

$$
W_{\hat{d} q}+W_{h q} Z=0
$$

以下に提案手法を具体的に示し, (6), (7) 式によりDVFB 制御が保持できることを示す。さらに,この手法によっ て設計される制御系全体が既存制御系の安定性を維持す ることも示す.

\section{1 提案手法}

提案手法により導かれるロバスト補償器を示す。まず, 外乱推定器 $\Gamma$ を構成する. $\Psi$ が列フルランクであるこ とに着目し, 次の正則な行列 $T \in \boldsymbol{R}^{m \times m}$ を定義する.

$$
T \equiv\left[\begin{array}{ll}
\Psi & \bar{\Psi}
\end{array}\right]
$$

ここで, $\bar{\Psi} \in \boldsymbol{R}^{m \times\left(m-n_{q}\right)}$ である. $T$ を用いると, 制御対 象の伝達関数行列 $P_{u y^{\star}}$ は $M \in \boldsymbol{F}^{2 m \times 2 m}, N \in \boldsymbol{F}^{2 m \times m}$ によって次のような多項式行列分解形で表現できる.

$$
P_{u y^{\star}}=M^{-1} N
$$




$$
M \equiv\left[\begin{array}{cccc}
L^{-1} & 0 & 0 & 0 \\
0 & I_{m-n_{q}} & 0 & 0 \\
-s I_{n_{q}} & 0 & I_{n_{q}} & 0 \\
0 & 0 & 0 & I_{m-n_{q}}
\end{array}\right]
$$

$$
N \equiv\left[\begin{array}{c}
\Psi^{\mathrm{T}} \\
0 \\
0 \\
0
\end{array}\right]
$$

ここで, $\operatorname{det}(M)$ はシステムの特性多項式の実数倍とな る. $\Gamma$ は $M, N$ を用いて次のように構成できる.

$$
\Gamma=\left[\begin{array}{ll}
M & -N
\end{array}\right]
$$

つぎに, ゼロイング要素 $Z$ を導出する. (14)式の分解 形より制御対象の伝達関数行列 $P_{\bar{d} y^{\star}}$ は次のようになる.

$$
\begin{aligned}
P_{\bar{d} y^{\star}} & =M^{-1} \\
& =\left[\begin{array}{cccc}
\Psi L & \bar{\Psi} & 0 & 0 \\
\Psi s L & 0 & \Psi & \bar{\Psi}
\end{array}\right]
\end{aligned}
$$

それぞれのブロック行列に等価外乱 $d_{1}, d_{2}, d_{3}, d_{4}$ を対 応させて, $\bar{d}=\left[d_{1}^{\mathrm{T}} d_{2}^{\mathrm{T}} d_{3}^{\mathrm{T}} d_{4}^{\mathrm{T}}\right]^{\mathrm{T}}$ とおく．また，(9), (10), (19) 式より $e=d_{1}$ である。 それぞれの等価外乱から $q$ までの伝達関数行列は次のようになる。

$$
\begin{aligned}
W_{d_{1} q} & =\left(L^{-1}-\Psi^{\mathrm{T}}\left(C_{w z}+C_{\bar{w} z} s\right) \Psi\right)^{-1} \\
& =W_{e q} \\
W_{d_{2} q} & =W_{e q} \Psi^{\mathrm{T}} C_{w z} \bar{\Psi} \\
W_{d_{3} q} & =W_{e q} \Psi^{\mathrm{T}} C_{\bar{w} z} \Psi \\
W_{d_{4} q} & =W_{e q} \Psi^{\mathrm{T}} C_{\bar{w} z} \bar{\Psi}
\end{aligned}
$$

$\Psi\left(\Psi^{\mathrm{T}} \Psi\right)^{-1}$ が $\Psi^{\mathrm{T}}$ の右疑似逆行列であることに着目す ると, $W_{h q}$ の右疑似逆行列 $W_{h q}^{\dagger}$ は

$$
W_{h q}^{\dagger}=C_{h z}^{-1} \Psi\left(\Psi^{\mathrm{T}} \Psi\right)^{-1} W_{e q}^{-1}
$$

となり,ここで $(6)$ 式を適用して $W_{\hat{d} q}=W_{\bar{d} q}$ とし， $(21) \sim(25)$ 式を用いると，(12) 式を満たす $Z$ は次の ように計算できる。

$$
\begin{aligned}
Z=- & W_{h q}^{\dagger} W_{\bar{d} q} \\
=- & C_{h z}^{-1} \Psi\left(\Psi^{\mathrm{T}} \Psi\right)^{-1} \\
& {\left[\begin{array}{llll}
I & \Psi^{\mathrm{T}} C_{w z} \bar{\Psi} & \Psi^{\mathrm{T}} C_{\bar{w} z} \Psi & \Psi^{\mathrm{T}} C_{\bar{w} z} \bar{\Psi}
\end{array}\right] }
\end{aligned}
$$

以上をまとめてロバスト補償器を構成する．Tの逆行 列を次のようにおく.

$$
T^{-1}=\left[\begin{array}{c}
\Psi^{\dagger} \\
\bar{\Psi}^{\dagger}
\end{array}\right]
$$

よって次式が成り立つ.

$$
\Psi \Psi^{\dagger}+\bar{\Psi} \bar{\Psi}^{\dagger}=I_{m}
$$

ロバスト補償器全体は, (7) 式を適用し (29) 式の関係 などを利用すると, 以下のように得られる。

$$
\begin{aligned}
& {\left[\begin{array}{lll}
R_{y_{p} h} & R_{y_{r} h} & R_{u h}
\end{array}\right]=F Z S \Gamma} \\
& =-f C_{h z}^{-1} \Psi\left(\Psi^{\mathrm{T}} \Psi\right)^{-1} \\
& \quad\left[\begin{array}{llll}
\Psi^{\mathrm{T}} C_{w z}+W_{e q}^{-1} \Psi^{\dagger} & \Psi^{\mathrm{T}} C_{\bar{w} z} & -\Psi^{\mathrm{T}}
\end{array}\right]
\end{aligned}
$$

\subsection{DVFB 制御の保持}

ロバスト補償器付加後の制御器全体の速度フィードバッ ク部分 ${ }_{R} C_{\bar{w} z}$ は $(30)$ 式を用いると次のようになる.

$$
\begin{aligned}
{ }_{R} C_{\bar{w} z}= & \left(I_{m}-C_{h z} R_{u h}\right)^{-1}\left(C_{\bar{w} z}+C_{h z} R_{y_{r} h}\right) \\
= & \left(I_{m}-f \Psi\left(\Psi^{\mathrm{T}} \Psi\right)^{-1} \Psi^{\mathrm{T}}\right)^{-1} \\
& \quad\left(I_{m}-f \Psi\left(\Psi^{\mathrm{T}} \Psi\right)^{-1} \Psi^{\mathrm{T}}\right) C_{\bar{w} z} \\
= & C_{\bar{w} z}
\end{aligned}
$$

既存制御器の $C_{\bar{w} z}$ が DVFB 制御であることより, ${ }_{R} C_{\bar{w} z}$ において DVFB 制御が保持されることがわかる.

\section{3 制御系全体の安定性}

ロバスト補償器を含む全体のフィードバック制御器の 伝達関数行列は (33) 式と次式で与えられる.

$$
{ }_{R} C_{w z}=C_{w z}-f(1-f)^{-1} \Psi\left(\Psi^{\mathrm{T}} \Psi\right)^{-1} W_{e q}^{-1} \Psi^{\dagger}
$$

これらを (21) 式に適用し， $\Psi^{\dagger} \Psi=I_{m}$ などに注意して まとめると, ${ }_{R} W_{e q}$ は次式のように表せる.

$$
{ }_{R} W_{e q}=(1-f) W_{e q}
$$

$C_{w^{\star} z}, C_{h z}$ が定係数行列であることと $(11),(21),(30)$ 式よりロバスト補償器の次数は $f$ と等しく, その分の次 数増加が $(35)$ 式の $1-f$ にあたる. $f$ は安定であるか ら, (35) 式より (30) 式のロバスト補償器の付加は既存 制御系の安定性を変えないことがわかる.

\section{4. おわりに}

DVFB 制御を保持する RMM を拡張した。これによ りアクチュエータの数が，制御設計用モデルにおける剛 体・柔軟モードの数よりも多い, 大規模な柔軟構造物の 設計を行うことが可能になった。

\section{参考文献}

1) 花島, 栄坂, 柳田, 土谷, 田川: Collocated feedback 制御 系のロバストモデルマッチングによる低感度化 ; システム制 御情報学会論文誌, Vol. 7, No. 2, pp. 51-58 (1994)

2) S. M. Joshi: Control of Large Flexible Space Structures, Springer-Verlag (1989) 